\title{
A Comparative Study of the Intelligence of White and Colored Children
}

\section{R. A. Schwegler \& Edith Winn}

To cite this article: R. A. Schwegler \& Edith Winn (1920) A Comparative Study of the Intelligence of White and Colored Children, The Journal of Educational Research, 2:5, 838-848, DOI: 10.1080/00220671.1920.10879119

To link to this article: http://dx.doi.org/10.1080/00220671.1920.10879119

曲 Published online: 15 Dec 2014.

Submit your article to this journal \lceil

Q View related articles $₫$

4 Citing articles: 2 View citing articles ๘ 


\title{
A COMPARATIVE STUDY OF THE INTELLIGENCE OF WHITE AND COLORED CHILDREN
}

\author{
R. A. SCHWEGLER \\ School of Education, Universily of Kansas \\ AND \\ EDITH WINN \\ High School, Neodesha, Kansas
}

Recent events in our national history have once more forced the question of the education of the American negro sharply into the foreground. Much has, of course, already been done by way of providing educational facilities for negro children. In the north there has been little or no attempt at differentiation. The white and the colored child have been freely admitted to equal educational opportunity. The south naturally has viewed its problem from a different angle, but even there state agencies have been awakened by patriotic, religious, and philanthropic forces to a new and productive interest in education for the colored race, until it may be said that at least the administrative aspects of the matter are in a fair way of being solved.

But the experience of unbiased educators has uniformly been that for some reason the negro child does not function in the American school as the white child does. All available statistics point to a higher school mortality, and to a markedly higher ratio of retardation. Various reasons have been given for this state of affairs. It has been asserted that the social status and traditions of the negro encourage meager intellectual standards, and that this is reflected in the school achievements of the negro child. By others it has been claimed that race differences of a fundamental type are involved, that the mentality of the negro child is essentially different from that of the white child, making identical standards both unfair and unwise. Of all the many explanations offered, these two have been most persistently and plausibly stated. It seems wise to attack the problem by a series of careful, unbiased investigations. Prejudiced opinion is rarely a good vehicle for truth.

This paper is an attempt to study the relative intelligence of white and colored children by the use of scientifically reliable 
devices. It is perhaps only fair to say that the study was undertaken with a distinct bias in favor of the colored child. Three questions were raised: (1) what is the relative intelligence of the two races; (2) what is the relative intelligence of colored boys and girls; and (3) in what particular types of function, if any, is the difference between the two races most striking.

Among the first attempts to measure the mental endowment of the negro by an intelligence scale was that of Miss Alice C. Strong in 1913. The Binet test was given to 225 white and to 125 colored children of Columbia, South Carolina. Josiah Morse, in reporting the study, calls attention to the fact that while 29.4 percent of the colored children were found to be backward more than one year, only 10.2 percent of the white children were so retarded. He also points out that only 0.8 percent of the colored children were one or more years advanced, while 5.3 percent of the white children were thus advanced. Morse emphasizes the fact that the mental level of the colored children approximates that of a typical mill population. Discussing the question of special abilities, he calls attention to the fact that colored children excel in rote memory, naming words, making rhymes, and in time orientation, while they are clearly inferior to white children in aesthetic judgment, observation, reasoning, motor control, logical memory, use of words, resistance to suggestion, and in orientation to the complexities of civilized society. He finds also that according to the Binet scale, a somewhat larger number of white children are in a grade below than in a grade above the one corresponding to their mental ability, and that the reverse is true of colored children. Morse concludes his remarks on Miss Strong's study with the statement that "negro children from 6 to 12 and possibly to 15 years are mentally different from, and also younger than, southern white children of corresponding ages."

B. A. Phillips reports the results of a comparative study of negro and white children in the elementary schools of Philadelphia. Both mental and environmental factors were here taken into account, and it was found that whereas 42.1 percent of white children were retarded, 68.4 percent of the colored children were so handicapped. A general survey of the tests again shows that "colored pupils as a class were good in memory tests and poor in those requiring judgment." 
Lacy, in a study of one hundred retarded pupils in the fourth grade at Evanston, Illinois, found that the differences in the distribution of the intelligence quotients of the colored and white children was very marked, and that the median intelligence quotient of the white children was at every age superior to that of the colored children. "On the whole the intelligence of the colored children is inferior to that of the white children."

A variety of tests other than the Binet scale has been employed in studying the relative intelligence of the two types of children. Thus, studies employing tests of cancellation, quickness of learning, substitution, completion, association, and memory are reported. The findings are all substantially as above reported. For fuller details the reader is referred to the bibliography appended to this paper.

The results herewith reported are derived from a careful study of 116 pupils drawn from the seventh and eighth grades of the junior high school of Lawrence, Kansas. The total colored enrollment in this school was 58 , there being 24 boys and 34 girls. A chance selection of an equal number of white boys and girls was made from the enrollment cards. The names of the children so selected were, with one exception, wholly unknown to the examiners. These two groups of children were tested under uniformly favorable conditions by the use of the Stanford-Binet scale, arranged for use as a point scale. Each child was given a chance at every test, in order to assure perfect fairness, and to secure all the advantage of wide range testing.

The children were tested singly, the time required for each child varying from one to two hours, depending upon the promptness of the child's response to each test. The work was done during school hours in the school building during the first four months of 1919. It is of interest to note that on the whole the colored children appeared more at ease with the examiner than did the white children. Some of the white children seemed nervous and fearful lest they fail in the test. The fear of failure seemed to be alien to the colored children's minds. For the most part, they manifested an attitude of willingness to cooperate, and they seemed quite as interested and attentive as were the white children.

Considering the fact that at Lawrence the two races have identical school facilities throughout, and that environmental 
conditions are perhaps as nearly equal as they are anywhere in the United States, the conclusions derived from this study should have at least a fair degree of reliability.

The distribution of chronological ages of the children selected for this study may readily be seen from Table $I$.

TABLE I. DISTRIBUTION OF CHRONOLOGICAL AGES

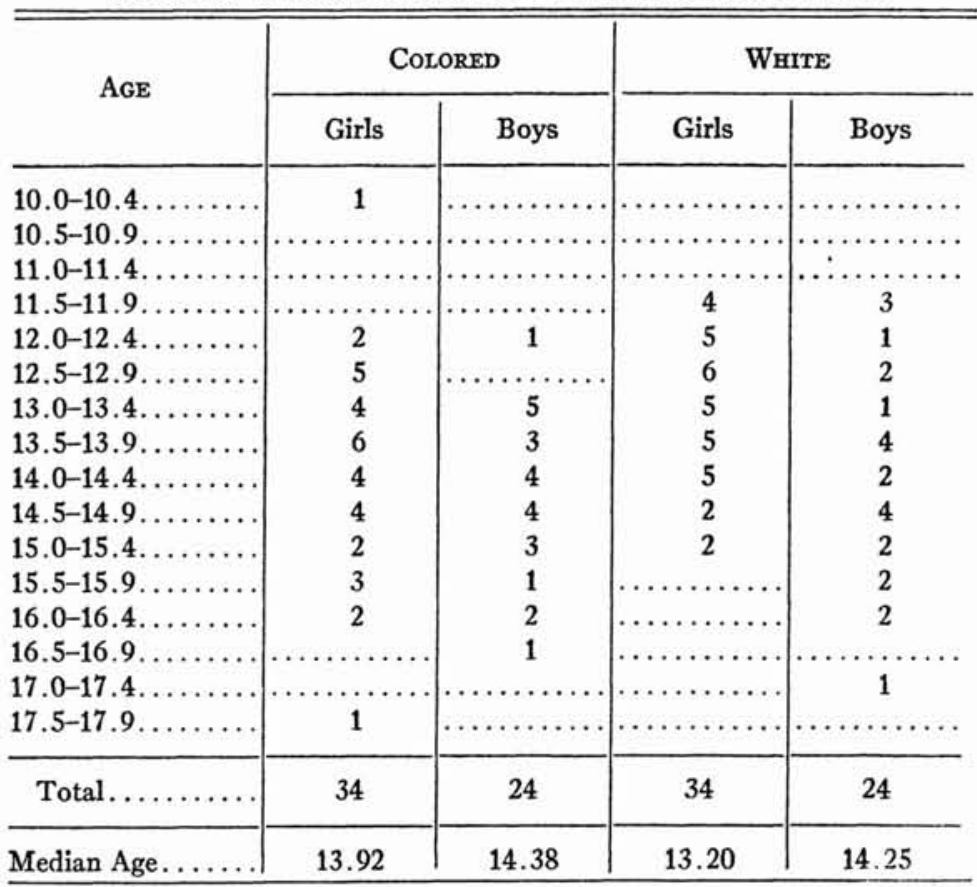

A brief study of Table I reveals the fact that the distribution of the chronological ages of the white and colored children is fairly similar. The median age for the colored girls and boys is respectively 13.92 and 14.38 , while that of the white girls and boys is respectively 13.20 and 14.25 years. The girls in each racial group are somewhat younger than the boys, though the difference between the median ages of the colored boys and girls is not as great as it is in the case of the white boys and girls. The median age of the colored group is 14.13 , while that of the white group is 13.61 .

The results of the mental tests as applied to these children are set forth in Table II, which shows the distribution of mental ages. 
TABLE II. DISTRIBUTION OF MENTAL AGES

\begin{tabular}{|c|c|c|c|c|}
\hline \multirow{2}{*}{ Mental Age } & \multicolumn{2}{|c|}{ CoLORED } & \multicolumn{2}{|c|}{ WHITE } \\
\hline & Girls & Boys & Girls & Boys \\
\hline $9.0-9.4 \ldots \ldots \ldots$ & 1 & & & \\
\hline $9.5-9.9 \ldots \ldots \ldots$ & & 1 & & 1 \\
\hline $10.0-10.4 \ldots \ldots \ldots$ & 2 & 3 & 2 & 1 \\
\hline $10.5-10.9 \ldots \ldots \ldots$ & 2 & & & \\
\hline $11.0-11.4 \ldots \ldots \ldots$ & 4 & 2 & 1 & 1 \\
\hline $11.5-11.9 \ldots \ldots \ldots$ & 6 & 3 & $\ldots$ & 1 \\
\hline $12.0-12.4 \ldots \ldots \ldots$ & 7 & 2 & 4 & 2 \\
\hline $12.5-12.9 \ldots \ldots \ldots$ & 2 & 3 & 2 & 1 \\
\hline $13.0-13.4 \ldots \ldots \ldots$ & 3 & 4 & 5 & 3 \\
\hline $13.5-13.9 \ldots \ldots \ldots$ & 1 & & 4 & 5 \\
\hline $14.0-14.4 \ldots \ldots \ldots$ & 5 & 3 & 5 & 4 \\
\hline $14.5-14.9 \ldots \ldots \ldots$ & 1 & 2 & 3 & 2 \\
\hline $15.0-15.4 \ldots \ldots \ldots$ & (n..., & 1 & 4 & 1 \\
\hline $15.5-15.9 \ldots \ldots \ldots$ & n......... & ........... & 1 & 1 \\
\hline $16.0-16.4 \ldots \ldots \ldots$ & . & …… & 2 & 1 \\
\hline $16.5-16.9 \ldots \ldots \ldots$ & n......... & n.w. & 1 & n.w. \\
\hline Total........... & 34 & 24 & 34 & 24 \\
\hline Median Age....... & 12.14 & 12.67 & 13.88 & 13.70 \\
\hline
\end{tabular}

The median mental age of colored girls according to this table is 12.14, that of white girls is 13.88 . In like manner the median mental age of colored boys is 12.67 against 13.7 for white boys. The ratio between these median mental ages and the median chronological ages already presented in Table $I$ can be tersely expressed in the form of median group intelligence quotients. For the colored girls, colored boys, white girls, and white boys these ratios are respectively, $0.872,0.881,1.052$, and 0.961 , from which it would appear clearly that there is an appreciable difference between the mental performance of the two racial groups.

The question can, however, be studied from another angle. Table III presents the distribution of the actual intelligence quotients derived from the test results. A study of this table should be useful, for it will bring to the surface in sharp relief the general tendencies which intelligence quotients seem to follow. 
TABLE III. DISTRIBUTION OF INTELLIGENCE QUOTIENTS

\begin{tabular}{|c|c|c|c|c|}
\hline \multirow{2}{*}{$\begin{array}{l}\text { INTELLIGENCE } \\
\text { QUOTIENT }\end{array}$} & \multicolumn{2}{|c|}{ COLORED } & \multicolumn{2}{|c|}{ WhIte } \\
\hline & Girls & Boys & Girls & Boys \\
\hline $60-64 \ldots \ldots \ldots \ldots$ & 1 & & & 2 \\
\hline $65-69 \ldots \ldots \ldots \ldots$ & 1 & 4 & 1 & 1 \\
\hline $70-74 \ldots \ldots \ldots \ldots$ & 3 & $\ldots \ldots \ldots \ldots$ & 1 & 1 \\
\hline $75-79 \ldots \ldots \ldots \ldots$ & 4 & 1 & 1 & 1 \\
\hline $80-84 \ldots \ldots \ldots \ldots$ & 2 & 2 & 1 & $\ldots \ldots \ldots \ldots$ \\
\hline $85-89 \ldots \ldots \ldots \ldots$ & 7 & 6 & 2 & 4 \\
\hline $90-94 \ldots \ldots \ldots \ldots$ & 7 & 7 & 2 & 1 \\
\hline $95-99 \ldots \ldots \ldots \ldots$ & 3 & $\ldots \ldots \ldots \ldots$ & 3 & 2 \\
\hline $100-104 \ldots \ldots \ldots \ldots$ & 3 & 1 & 5 & 4 \\
\hline $105-109 \ldots \ldots \ldots \ldots$ & 1 & 2 & 5 & 3 \\
\hline $110-114 \ldots \ldots \ldots \ldots$ & 1 & $\ldots \ldots \ldots$ & 3 & $\ldots \ldots \ldots \ldots$ \\
\hline $115-119 \ldots \ldots \ldots \ldots$ & $\cdots \cdots$ & $\ldots \ldots \ldots \ldots$ & 2 & $\ldots \ldots \ldots \ldots$ \\
\hline $120-124 \ldots \ldots \ldots \ldots$ & $\cdots \cdots$ & 1 & 3 & 4 \\
\hline $125-129 . \ldots \ldots \ldots \ldots$ & $\ldots \ldots$ & $\ldots \ldots \ldots$ & 4 & 1 \\
\hline $130-134 \ldots \ldots \ldots \ldots$ & $\cdots \cdots$ & & $\cdots$ & $\ldots \ldots \ldots \ldots$ \\
\hline $135-139 . \ldots \ldots \ldots \ldots$ & 1 & $\ldots \ldots \ldots \ldots$ & 1 & $\ldots \ldots \ldots \ldots$ \\
\hline Total........... & 34 & 24 & 34 & 24 \\
\hline Median I. Q...... & 89.3 & 89.2 & 106.0 & 100.0 \\
\hline
\end{tabular}

The intelligence quotient may be defined as the ratio of mental age to chronological age. Since it is being proposed and rather widely accepted as a reliable "measure of brightness," Table III takes on added significance, for it appears that while the actual median quotient of white girls is 106 , that of colored girls is only 89.3 ; and that while the median quotient of white boys is 100 , that of colored boys is 89.2 . If the groups be studied as wholes, then the intelligence quotient of the white children as a whole is 103.3, and that of the colored children as a group 89.2. Of the white children 74 percent exceeded the median I.Q. of the colored children, while only 12 percent of the colored children exceeded the median I.Q. of the white children.

Following Terman's grouping of intelligence quotients, Table IV may be constructed. This table is still more significant when it is understood that while the colored group represented all the children of that race in the Junior High School, the chanceselected white group "happened" to include a number of the dullest and none of the most brilliant. Some of the white children who were not included in the investigation had earned intelligence quotients well above 140 . 
TABLE IV. GROUPING OF COLORED AND WHITE CHILDREN ON THE BASIS OF BRIGHTNESS

\begin{tabular}{|c|c|c|c|}
\hline $\begin{array}{c}\text { INTELLIGENCE } \\
\text { QUOTIENT }\end{array}$ & DEgree of Brightness & COLORED & Wнгте \\
\hline 140 and above.... & Genius or near-genius.... & 0 & 0 \\
\hline $120-139 \ldots \ldots \ldots \ldots$ & Very superior........... & 2 & 13 \\
\hline $110-119 . . \ldots \ldots \ldots$ & Superior............... & 1 & 5 \\
\hline $90-109 \ldots \ldots$ & Average...$\ldots \ldots \ldots$. & 24 & 25 \\
\hline $80-89 \ldots \ldots$ & 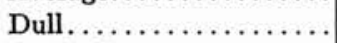 & 17 & 7 \\
\hline $70-79 \ldots \ldots$ & Borderline ............. & 8 & 4 \\
\hline Below $70 \ldots$. & Defective............ & 6 & 4 \\
\hline
\end{tabular}

Of the colored children 53.4 percent fall below 90 , the point designated by Terman as representing the lower limit of normal white intelligence. Of the white children only 26 percent fail to reach this level, which is quite compatible with a normal chance distribution. Of the white children 31 percent present superior intelligence or better, while only 5 percent of the colored children reach this level.

A careful analysis of the successes and failures in the individual tests of the Binet scale is illuminating, and may ultimately serve to throw some light on the problems raised in connection with the study of negro mentality. The facts are briefly as follows:

1. In all rote memory tests not involving reversing or other manipulation of reproduced material the two races were for the most part on an even footing, or in any case the difference was slight, and possibly due to chance factors.

2. In all memory tests that involved reversing or other manipulation of reproduced material the white children were markedly superior. The reason for this difference is difficult to see, unless there is involved an essential difference in function trends.

3. In all tests involving common sénse adjustment to practical situations of a fairly familiar type the colored children were clearly the equal of the white children. In fact, in some of the tests the colored boys outdid the white boys by a good margin. For example, the problem of "the ball lost in the field" was solved in a superior way by 62.5 percent of the colored boys, and by only 41.66 percent of the white boys. The white girls, however, surpassed the colored girls 64.7 to 52.94 . 
4. In all tests involving adjustment to practical situations that were unique, or that involved the consideration of somewhat remote contingencies of no matter how simple a type, the white children of both sexes were definitely superior. The white children were superior in problems which Terman calls "Problems of the third degree," 100 to 94.82 ; in arranging five weights in order 86.2 to 67.24 ; in reconstructing dissected sentences 84.48 to 44.82 .

5. All tests which involved abstract reasoning whether of analytic or synthetic type were passed more satisfactorily by the white children than by the colored children. Sometimes the margin was very wide, as in defining abstract words, 84.48 to 48.27 , in discovering absurdities 91.38 to 69 , and in noting differences between abstract terms, 41.38 to 12 .

6 . In all tests involving primarily verbal facility, the two races are practically on a par. There is a slight advantage on the side of the white children, but it is negligible.

7. In tests involving recognition of ideas, white children show a fairly clear advantage over the colored children. Terman's vocabulary test gives a mean of 38.48 words per colored child, and 48.04 per white child. If Terman's contention that the vocabulary test actually possesses diagnostic worth is ultimately established, then these performances take on a very definite meaning.

Table $\mathrm{V}$ presents in more concise form the specific findings in connection with the individual test groups above mentioned. From the values there stated, it becomes clear that each group tends to present characteristic capacity endowments, which may have a bearing on the economic, industrial, and social history of the two races.

It appears clear that in some types of mental function the colored group is quite the equal of the white group; but that in other functions, particularly in those which involve continuous and somewhat intense concentration of attention on subjectively developed and manipulated imagery the white group is clearly superior.

Incidental to the detailed study of the test results, it also appeared that while there was a clearly marked superiority of the white girls as compared with the white boys in nearly all the 
TABLE V. THE RELATIVE EFFICIENCY OF COLORED AND WHITE CHILDREN IN MENTAL TESTS

\begin{tabular}{|c|c|c|c|}
\hline Type of Tests & $\begin{array}{c}\text { Average } \\
\text { of Colored } \\
\text { Passing }\end{array}$ & $\begin{array}{c}\text { Average } \\
\text { of White } \\
\text { Passing }\end{array}$ & $\begin{array}{l}\text { Ratio of } \\
\text { Colored } \\
\text { to White }\end{array}$ \\
\hline Direct, non-manipulated reproduction (memory).... & 74.94 & 74.39 & 1.007 \\
\hline Reversed or otherwise manipulated reproduction.... & 47.28 & 57.52 & 0.822 \\
\hline Familiar common sense adjustments (orientation).. & 93.61 & 94.84 & 0.988 \\
\hline Adjustment to unfamiliar situations.............. & 36.2 & 58.18 & 0.622 \\
\hline Abstract reasoning $\ldots \ldots \ldots \ldots \ldots \ldots \ldots \ldots \ldots$ & 43.09 & 72.41 & 0.595 \\
\hline Verbal facility (common sense type)............ & 91.38 & 93.1 & 0.981 \\
\hline Vocabulary recognition $\ldots \ldots \ldots \ldots \ldots \ldots \ldots \ldots$ & 38.48 & 48.04 & 0.801 \\
\hline
\end{tabular}

Total net efficiency of colored group as compared with white group, 83.1 percent.

tests of the series, there was no such clear superiority of the colored girls over the colored boys. Table VI, derived from the undistributed data, shows the situation clearly in terms of intelligence quotients.

TABLE VI. RELATIVE INTELLIGENCE OF COLORED BOYS AND GIRLS AND OF WHITE BOYS AND GIRLS

\begin{tabular}{c|c|c|c}
\hline Group & Median I. Q. & Range & Variability \\
\hline Colored boys.......... & 89.2 & 0.65 to 1.23 & 1.43 \\
Colored girls............ & 89.3 & 0.64 to 1.36 & 1.59 \\
White boys.......... & 99 & 0.62 to 1.25 & 1.82 \\
White girls........... & 106 & 0.67 to 1.37 & 1.52 \\
\hline
\end{tabular}

The physical and mental precociousness of the white girl undoubtedly accounts in part for the relation above revealed. The intelligence of the white boys in this group is 94 percent of that of the white girls. The intelligence of the colored boys is 100 percent of that of the colored girls. One is tempted to ask whether perhaps the growth rhythm of the two races may not be essentially different, and whether the well-recognized difference between the intellectual life of adolescent white boys and girls is also characteristic of colored adolescent children. The groups studied were too small to draw final conclusions, but a significant question is here raised. 
The findings of this study coincide in all essential points with those published by others. There appears to be an unmistakable difference in the intellectual life of the two groups studied. The median intellectual endowment of the colored group is about 85 percent of that of the white group. This difference, however, does not extend over the whole range of mental performances, but is highly specialized. In some types of function, namely, those that involve direct unmanipulated recall, in common sense adjustments to simple situations, and in verbal facility the two groups are equal in ability. But in all functions that involve intensive concentration of attention on complex subjective activities of a rational type the white group has a distinctly greater ability. The difference lies essentially in the higher and more abstract types of psychic work. That the difference is fundamental is indicated by the very fact that the colored children approached the test cheerfully and without concern as to the outcome, while the white children were obviously concerned lest they "fail the test." One group functioned in terms of the obvious, the other in terms of the related possibilities.

This study labors under the disadvantage of serious limitations. The groups studied were small, and therefore subject to distortion. But most serious of all is the fact that the tests employed were only adequate for the study of intelligence and touched the large field of other psychic functions inferentially or not at all. Perhaps the colored group compensates in some particular for its shortcoming in intellectual function.

\section{BIBLIOGRAPHY}

BALDwin, B. T. "The learning of delinquent adolescent girls as shown by a substitution test," Journal of Educational Psychology, 4:317-32, June, 1913.

BRUner, F. G. "Racial differences," Psychological Bulletin, 11:384-86, October 15, 1914.

Calloway, Clinton J. "Co-operative school building," Southern Workman, 48: 236-41, May, 1919.

Eggleston, Edward. The ultimate solution of the American negro problem. Boston: Richard G. Badger, 1913. 285 pp.

Ferguson, George O. The psychology of the negro: an experimental shidy. (Archives of Psychology, no. 36.) New York: Science Press, 1916, 138 pp.

LACY, W. I. "A study of one hundred retarded fourth-grade pupils tested by the Binet scale," Psychological Clinic, 12:16-24, March 15, 1918. 
LIND, JoHn E. Diagnostic pitfalls in the mental examinations of negroes. (Reprinted from the New York Medical Journal, June 27, 1914.)

Mayo, M. J. The mental capacity of the American negro. (Archives of Psychology, no. 28.) New York: Science Press, 1913. 70 pp.

Morse, Josiah. "A comparison of white and colored children measured by the Binet scale of intelligence," Popular Science Monthly, 84:75-79, January, 1914.

Negro education. (Reprinted from United States Bureau of Education Bulletin, 1916, nos. 38-39.)

Phillips, B. A. " "Retardation in the elementary schools of Philadelphia," Psychological Clinic, 6:79-90, May 15, 1912.

Phillips, B. A. "The Binet tests applied to colored children," Psychological Clinic, 8:190-96, December 15, 1914.

Pyle, W. H. "The mind of the negro child," School and Society, 1:357-60, March 6, 1915.

Stetson, G. R. "Some memory tests of whites and blacks," Psychological Review, 4:285-89, May, 1897.

Strong, A. C. "Three hundred fifty white and colored children measured by the Binet Simon measuring scale of intelligence," Pedagogical Seminary, 20:485-515, December, 1913.

Terman, Lewis M. The measurement of intelligence. Boston: Houghton Mifflin Co., 1916, 362 pp.

Wasmington, Booker T. Working with the hands. New York: Doubleday Page and Company, 1904. 246 pp. 